\title{
PROMOSI KESEHATAN IBU DAN ANAK \\ MELALUI CORPORATE SOCIAL RESPONSIBILITY (CSR) BIDANG KESEHATAN IBU DAN ANAK
}

\author{
Gina Indah P. Nastia, Hadiyanto A. Rachim, Maulana Irfan \\ gyn_nastia@yahoo.co.id,hrachim@yahoo.co.id, mifran_crb@yahoo.com
}

\begin{abstract}
ABSTRAK
Artikel ini yang berjudul Promosi Kesehatan Ibu dan Anak Melalui Corporate Social Responsibility (CSR) Bidang Kesehatan Ibu dan Anak, memiliki tujuan untuk memberikan gambaran mengenai kondisi kesehatan masyarakat di Indonesia, yang masih tergolong rendah akibat masih tingginya Angka Kematian Ibu dan Anak, yang disebabkan oleh faktor pendidikan masyarakat yang rendah di bidang kesehatan, faktor lingkungan yang tidak memadai, faktor pemanfaatan layanan kesehatan, dan status gizi masyarakat yang rendah. Selain itu, artikel ini pun memberikan penjelasan mengenai pentingnya pelaksanaan CSR di bidang kesehatan ibu dan anak, dan juga menjelaskan mengenai upaya peningkatan kesehatan ibu dan anak yang hendaknya dilakukan dalam pelaksanaan kegiatan CSR di bidang kesehatan ibu dan anak. Kesehatan ibu dan anak merupakan tolok ukur yang sangat penting bagi terciptanya generasi penerus bangsa yang berkualitas. Oleh sebab itu, konsep-konsep berkaitan dengan upaya promosi kesehatan ibu dan anak akan ditelaah lebih jauh dalam artikel ini.
\end{abstract}

Kata kunci: Corporate Social Responsibility, Kesehatan Ibu dan Anak, Angka Kematian Ibu dan Anak, Promosi Kesehatan

\begin{abstract}
This article titled Mother and Child's Health Promotion Through Corporate Social Responsibility (CSR) in Mother and Child's Health Field, has the aim to give a description of society's low health condition in Indonesia, effected by the high Number of Maternal and Child's Death, which caused by society's low education in health field, inadequate environment, health services functioning, and society's nutrition status factors. Besides it, this article also gives the explanation of the importance of CSR activities in mother and child's field, and it also explains about the mother and child's health promotion which should be attemped in the implementation of CSR activities in mother and child's healtf field. Mother and child's health is the most important benchmark in creating good qualities of nation's future generation.

Keywords: Corporate Social Responsibility, Mother ad Child's Health, Number of Maternal and Child's Death, Health Promotion

\section{PENDAHULUAN}

Pembangunan nasional mencakup pertumbuhan ekonomi, perawatan masyarakat, dan pengembangan manusia. Fungsi pertumbuhan ekonomi menunjuk pada bagaimana melakukan wirausaha guna memperoleh pendapatan finansial yang dibutuhkan untuk membiayai kegiatan pembangunan. Fungsi perawatan masyarakat menunjuk pada bagaimana merawat dan melindungi warga negara

dari berbagai macam resiko yang mengancam kehidupannya. Dalam hal ini, fungsi perawatan masyarakat mencakup sektor kesehatan dan kesejahteraan masyarakat. Sementara itu, fungsi pengembangan manusia menunjuk pada peningkatan kompetensi sumber daya manusia yang mampu menjamin tersedianya angkatan kerja yang berkualitas guna mendukung pembangunan. Fungsi pengembangan
\end{abstract}


manusia dalam hal ini mencakup sektor pendidikan. Oleh karena itu, agar pembangunan nasional berjalan secara optimal dan mampu bersaing secara global, maka ketiga aspek tersebut harus diperhatikan secara seimbang. Hal ini dikarenakan fungsi pertumbuhan ekonomi diperlukan untuk menjalankan fungsi perawatan masyarakat dan fungsi pengembangan manusia. Sementara itu, fungsi perawatan dan pengembangan manusia juga memiliki posisi yang tak kalah penting, yakni kedua fungsi tersebut merupakan substansi dari pembangunan sosial yang mampu menopang pembangunan ekonomi dan mendukung pertumbuhan ekonomi secara berkelanjutan (Suharto, 2005: 5).

Sebagaimana yang telah dikemukakan sebelumnya, kesehatan merupakan salah satu indikator yang mampu menopang pembangunan nasional disamping pendidikan dan ekonomi, sehingga kesehatan masyarakat dalam hal ini harus menjadi perhatian seluruh pihak, baik pemerintah, swasta, maupun masyarakat untuk mencapai kesejahteraan masyarakat (Suharto, 2007). Besarnya Angka Indeks Kesehatan, salah satunya dapat dipengaruhi oleh besarnya Angka Kematian Ibu dan Anak di suatu wilayah (www.bkkbn.go.id, diakses 21 Juni 2014, pukul 21.11 WIB).

Di Indonesia, tingkat kesehatan masyarakat justru masih rendah jika dibandingkan dengan negara-negara tetangga lainnya, seperti Singapura, Malaysia, Thailand, dan Filipina, bahkan Vietnam. Hal ini dilihat dari besarnya Angka Harapan Hidup (AHH) di Indonesia. Angka Harapan Hidup (AHH) di Indonesia memang meningkat dari tahun ke tahun, namun laju peningkatan tersebut sangat lambat. Hal ini salah satunya dikarenakan masih tingginya Angka Kematian Ibu dan Anak (www. health.kompas.com, diakses 8 April 2014, pukul 13.52). Menurut buku Data dan Informasi Kinerja Pembangunan 20042012 Republik Indonesia, dari tahun ke tahun, Indonesia mengalami laju penurunan Angka Kematian Ibu yang lambat sebagai berikut.

\section{Gambar I}

Angka Kematian Ibu di Indonesia Tahun 1991-2007

Sumber: Badan Pusat Statistik, Survey

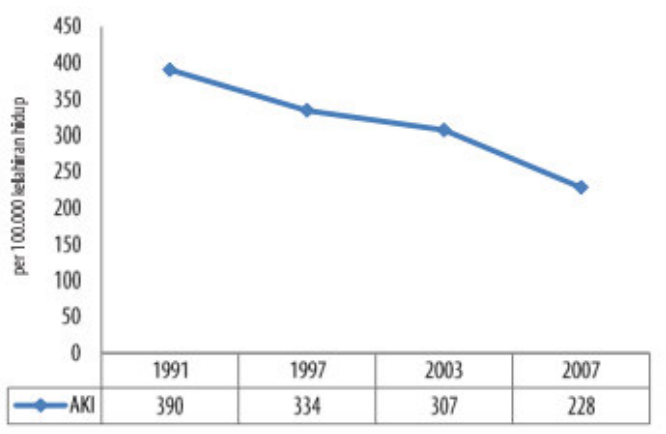

Demografi dan Kesehatan Indonesia (SDKI)

Dari gambar yang telah dikemukakan sebelumnya, dapat diketahui pada tahun 1991, angka tersebut mencapai 390. Pada tahun 1997, angka tersebut mencapai 334. Pada tahun 2003, angka tersebut mencapai 307. Pada tahun 2007, angka tersebut mencapai 228. Selain itu, laju penurunan Angka Kematian Bayi pun pada tahun 1991 hingga 2012 lambat. Hal ini dapat dilihat pada gambar sebagai berikut.

\section{Gambar II}

Angka Kematian Bayi di IndonesiaTahun 1991-2012

Demografi dan Kesehatan Indonesia (SDKI)

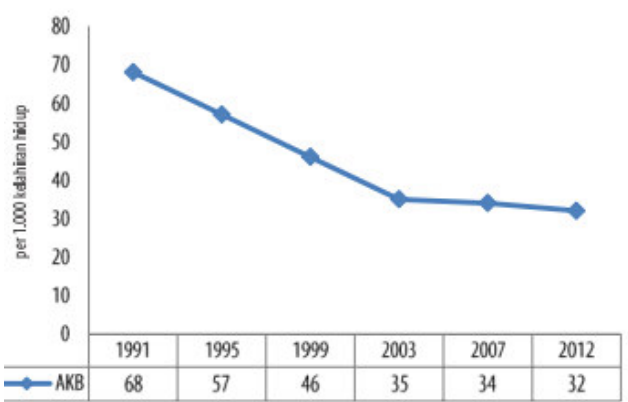

Sumber: Badan Pusat Statistik, Survey 
Berdasarkan gambar yang telah dikemukakan sebelumnya, dapat diketahui pada tahun 1991, angka tersebut mencapai 68. Pada tahun 1995, angka tersebut mencapai 57. Pada tahun 1999, angka tersebut mencapai 46. Pada tahun 2003, angka tersebut mencapai 35. Pada tahun 2007, angka tersebut mencapai 34. Pada tahun 2012, angka tersebut mencapai 32.

Selain itu, masih terdapat wilayah yang memiliki Angka Kematian Ibu dan Anak yang tinggi di Indonesia, salah satu contohnya adalah Kabupaten Garut. Kabupaten Garut merupakan salah satu kabupaten di Provinsi Jawa Barat yang capaian Indeks Kesehatannya sebesar 68,90 poin. Angka tersebut masih berada di bawah capaian Indeks Kesehatan Provinsi Jawa Barat, yakni sebesar 72,67 poin. Hal ini dipengaruhi oleh Angka Kematian Ibu dan Angka Kematian Bayi yang masih tinggi (www.inilahkoran.com, diakses 20 September 2014, pukul 11.59 WIB). Menurut data Departemen Kesehatan, pada tahun 2012, jumlah kematian ibu hamil di Kabupaten Garut mencapai 9 kasus, jumlah kematian ibu bersalin sebanyak 12 kasus, dan jumlah kematian ibu nifas sebanyak 7 kasus. Sementara itu, jumlah kematian bayi di Kabupaten Garut mencapai 298 kasus dan jumlah kematian anak balita mencapai 15 kasus. Dari jumlah tersebut, sebanyak 52 persen kasus kematian bayi disebabkan oleh Berat Badan Lahir Rendah. Selain itu, menurut Badan Pusat Statistik Kabupaten Garut, laju penurunan Angka Kematian Bayi di Kabupaten Garut setiap tahunnya lambat. Hal ini dapat dilihat pada deskripsi laju penurunan Angka Kematian Bayi di Kabupaten Garut pada tahun 2009 hingga 2012 sebagai berikut.
Gambar III

Angka Kematian Bayi di KabupatenGarut

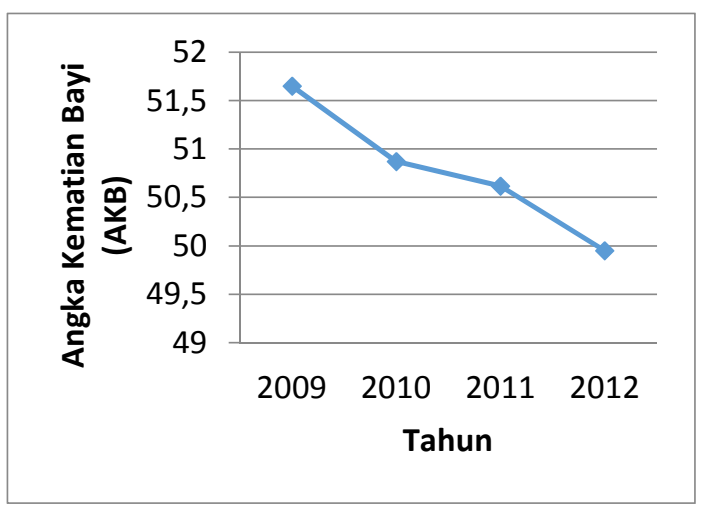

Tahun 2009-2012

Sumber: BPS Kabupaten Garut, 2012

Dari gambar yang telah dikemukakan sebelumnya, dapat diketahui bahwa Angka Kematian Bayi di Kabupaten Garut mencapai 51,65 pada tahun 2009. Kemudian pada tahun 2010, angka tersebut turun menjadi 50,87. Pada tahun 2011, angka tersebut kembali menurun, yaitu mencapai 50,62, dan pada tahun 2012 Angka Kematian Bayi di Garut mencapai 49,95. Lambatnya penurunan Angka Kematian Bayi dan masih tingginya Angka Kematian Ibu dan Anak di Kabupaten Garut ini diantaranya dikarenakan faktor ekonomi, faktor pemanfaatan layanan, kualitas sarana dan prasarana yang kurang memadai, serta perilaku dan pendidikan masyarakat yang minim di bidang kesehatan

(www.fokusjabar.com, diakses 14 Juni 2014, pukul 0.09 WIB).

Menurut Badan Pusat Statistik Kabupaten Garut, rendahnya pendidikan masyarakat di bidang kesehatan, khususnya dalam hal perawatan ibu selama hamil dan proses melahirkan anak serta pemberian nutrisi yang cukup bagi ibu dan balitanya, berakibat pada tingginya angka kematian ibu dan bayi. Penanganan proses kelahiran dengan pertolongan tenaga non medis, merupakan fenomena yang masih banyak terjadi di masyarakat ini. Hal ini berakibat pada tidak terselamatkannya ibu dan/atau anak (www.garutkab.bps.go.id, diakses 8 Mei 2014, pukul 14.09 WIB). Berbagai upaya telah dilakukan untuk 
mengatasi masalah kesehatan di Indonesia, dan salah satunya adalah oleh perusahaan melalui program kepeduliannya terhadap masyarakat, yang disebut dengan Corporate Social Responsibility (CSR).

Indonesia merupakan negara yang kaya dengan sumber daya alam. Kekayaan sumber daya alam ini mengundang kehadiran berbagai perusahaan eksploratif di Indonesia, seperti PT. Pertamina, PT. Chevron Geothermal Indonesia, PT. Indonesia Power, dan lain sebagainya. Sebagai perusahaan yang aktivitas bisnisnya menggunakan sumber daya alam, perusahaan-perusahaan tersebut memiliki kewajiban untuk melaksanakan kegiatan tanggungjawab sosialnya kepada masyarakat (CSR). Hal ini diatur dalam Undang-Undang No. 40 Tahun 2007 tentang Perseroan Terbatas, sebagai berikut:

- Perseroan yang menjalankan kegiatan usahanya di bidang sumber daya alam wajib melaksanakan Tanggung Jawab Sosial dan Lingkungan

- Tanggung Jawab Sosial dan Lingkungan sebagaimana dimaksud ayat (1) merupakan kewajiban Perseroan yang dianggarkan dan diperhitung-kan sebagai biaya Perseroan yang pelaksanaannya dilakukan dengan memperhatikan kepatutan dan kewajaran.

- Perseroan yang tidak melaksanakan kewajiban sebagaimana dimaksud pada ayat (1) dikenai sanksi sesuai dengan ketentuan peraturan perundang-undangan.

Sementara itu, bagi perusahaan Badan Usaha Milik Negara, kewajiban melaksanakan Program Kemitraan dan Bina Lingkungan (PKBL) ini pun diatur dalam Peraturan Menteri Negara BUMN Tahun 2007 Pasal 2 yang berbunyi sebagai berikut:

"Persero dan Perum wajib melaksanakan Program Kemitraan BUMN dengan Usaha Kecil dan
Program Bina Lingkungan. Sedangkan Persero Terbuka dapat me-laksanakan Program Kemitraan BUMN dengan Usaha Kecil dan Program Bina Lingkungan dengan berpedoman pada Permen BUMN 5/2007 yang ditetapkan berdasarkan keputusan RUPS."

Kesehatan masyarakat di Indonesia merupakan salah satu fenomena yang perlu diperhatikan oleh perusahaan, disamping ekonomi dan pendidikan. Kegiatan CSR dalam bentuk karitas saja kini belum cukup untuk memperbaiki dan meningkatkan kondisi kesehatan masyarakat yang rendah, terutama kesehatan ibu dan anak. Hal ini dikarenakan kegiatan CSR yang bersifat karitas tidak dapat merespon kebutuhan masyarakat dan menyentuh perhatian masyarakat, namun hanya akan menimbulkan berbagai permasalahan baru, seperti ketergantungan masyarakat terhadap bantuan perusahaan (Suharto, 2008). Oleh karena itu, pemeliharaan dan promosi kesehatan merupakan upaya yang sebaiknya dilakukan dalam kegiatan CSR perusahaan guna menurunkan Angka Kematian Ibu dan Anak serta meningkatkan kesehatan ibu dan anak di Indonesia. Upaya pemeliharaan dan peningkatan kesehatan ibu dan anak dalam pelaksanaan kegiatan CSR di bidang kesehatan ibu dan anak di Indonesia hendaknya dialamatkan pada empat determinan kesehatan, yakni perilaku, lingkungan (mencakup lingkungan fisik, sosial, budaya, politik, ekonomi, dan lain sebagainya), pelayanan kesehatan, dan hereditas. Dengan kata lain, upaya tersebut meliputi intervensi terhadap faktor perilaku, faktor lingkugan, faktor pelayanan kesehatan, dan faktor hereditas (Notoatmodjo, 2007: 11-13). Intervensi pada faktor perilaku meliputi pendidikan kesehatan. Intervensi terhadap faktor lingkungan meliputi perbaikan sanitasi lingkungan, peningkatan pendidikan, perbaikan sosial ekonomi masyarakat, 
penstabilan politik dan keamanan, dan sebagainya. Intervensi terhadap faktor pelayanan kesehatan meliputi penyediaan atau perbaikan fasilitas pelayanan kesehatan, perbaikan sistem dan manajemen pelayanan kesehatan, dan sebagainya. Sementara itu, intervensi terhadap faktor hereditas meliputi perbaikan gizi ibu hamil dan anak. Intervensi yang dilakukan terhadap keempat faktor tersebut dikatakan efektif apabila mampu memberikan dampak positif terhadap aspek kognitif, afektif, psikomotor, serta lingkungan eksternal masyarakat yang dapat mendukung kesehatan. Dalam hal ini, kegiatan CSR di bidang kesehatan ibu dan anak hendaknya bersifat promotif. PT. Pertamina merupakan salah satu perusahaan yang kegiatan CSR di bidang kesehatan ibu dan anaknya berupa promosi kesehatan yang telah dialamatkan pada keempat faktor tersebut.

Selain dialamatkan kepada keempat faktor kesehatan, upaya promosi kesehatan dalam kegiatan CSR di bidang kesehatan ibu dan anak pun hendaknya melibatkan berbagai ahli yang bekerja dalam ranah kesehatan masyarakat, seperti pekerja sosial klinis, perawat, pendidik kesehatan, psikiater, dan ahli non klinis, seperti epidemiologis, administrator, dan pembuat kebijakan. Sebelum kegiatan dilakukan, assessment dan penggalian informasi terkait dengan penyebaran penyakit, serta determinan kesehatan ibu dan anak di dalam masyarakat. Perusahaan dalam hal ini melalui kegiatan CSR memiliki peran untuk mencegah masyarakat dari penyakit serta mengorganisir berbagai ahli yang telah dikemukakan sebelumnya untuk memfasilitasi masyarakat (dalam Browne, 2006).

Kesehatan ibu dan anak merupakan tolok ukur yang sangat penting dalam menciptakan generasi penerus bangsa yang berkualitas, sehingga kegiatan CSR di bidang kesehatan ibu dan anak perlu dilaksanakan dalam rangka meningkatkan kesehatan masyarakat, serta memberikan manfaat dan kontribusi yang besar bagi kesehatan masyarakat, khususnya ibu dan anak.

\section{KESEHATAN MASYARAKAT}

Kesehatan merupakan salah satu indikator kesejahteraan masyarakat sekaligus salah satu indikator keberhasilan pembangunan (Suharto, 2007). Oleh karena itu, kesehatan masyarakat perlu diperhatikan untuk dapat menciptakan kesejahteraan dan pembangunan.

Menurut Undang-Undang No. 23 Tahun 1992, kesehatan didefinisikan sebagai berikut: "Kesehatan adalah keadaan sejahtera badan, jiwa, dan sosial yang memungkinkan setiap orang hidup produktif secara sosial dan ekonomi." Organisasi Kesehatan Dunia (WHO) pun pada tahun 1948 mendefinisikan kesehatan sebagai "suatu keadaan fisik, mental, dan sosial kesejahteran dan bukan hanya ketiadaan penyakit atau kelemahan". Kemudian pada tahun 1986, WHO dalam Piagam Ottawa untuk promosi kesehatan, menyebutkan bahwa kesehatan memiliki pengertian sebagai berikut: "Kesehatan merupakan sumber daya bagi kehidupan sehari-hari, bukan tujuan hidup. Kesehatan adalah konsep positif yang menekankan pada sumber daya sosial dan pribadi, serta kemampuan fisik."

Sementara itu, menurut Winslow (1920), kesehatan masyarakat didefinisikan sebagai berikut.

"Ilmu dan seni pencegahan penyakit, memperpanjang hidup, dan meningkatkan kesehatan melalui usaha-usaha pengorganisasian masyarakat untuk perbaikan sanitasi lingkungan, pemberantasan penyakit-penyakit menular, pendidikan untuk kebersihan perorangan, pengorganisasian pelayananpelayanan medis dan perawatan untuk diagnosis dini dan pengobatan, pengembangan rekayasa sosial untuk menjamin setiap orang terpenuhi kebutuhan 
hidup yang layak dalam memelihara kesehatannya."

Dari definisi yang telah dikemukakan sebelumnya, maka dapat disimpulkan bahwa kesehatan masyarakat merupakan suatu ilmu yang berkaitan dengan upaya-upaya peningkatan kesehatan yang memperhatikan aspek perilaku, lingkungan, pelayanan kesehatan, dan hereditas masyarakat, sehingga masyarakat mampu mandiri di bidang kesehatan.

Ilmu kesehatan masyarakat didasari oleh berbagai disiplin ilmu lainnya, yakni mencakup ilmu biologi, kedokteran, kimia, fisika, lingkungan hidup, sosiologi, antropologi, psikologi, dan ilmu pendidikan. Oleh karena itu, ilmu kesehatan masyarakat merupakan ilmu yang multidisiplin (Winslow, 1920).

\section{PROGRAM KESEHATAN IBU DAN ANAK}

Kesehatan ibu dan anak merupakan salah satu bagian dari kesehatan masyarakat. Kesehatan ibu dan anak merupakan kondisi yang sangat penting bagi bangsa di masa yang akan datang. Kesehatan seorang ibu, baik secara jasmani maupun rohani, sangat berpengaruh pada kelahiran anak yang sehat secara jasmani maupun rohani. Anak yang terlahir sehat merupakan aset penting bagi bangsa. Hal ini dikarenakan anak merupakan penentu nasib bangsa di masa yang akan datang. Oleh karena itu, kesehatan ibu dan anak harus diupayakan oleh seluruh pihak, baik pemerintah, Badan Usaha Milik Negara, Lembaga Swadaya Masyarakat, swasta, bahkan masyarakat itu sendiri. Upaya ini dapat dilakukan melalui Program Kesehatan Ibu dan Anak.

\section{PROMOSI KESEHATAN}

Promosi kesehatan sebagai bagian dari ilmu kesehatan, juga memiliki dua sisi, yakni sisi ilmu dan seni. Dari sisi seni, yakni praktisi promosi kesehatan merupakan penunjang bagi program- program kesehatan lain. Artinya, setiap program kesehatan, misalnya pemberantasan penyakit, perbaikan gizi masyarakat, sanitasi lingkungan, kesehatan ibu dan anak, program pelayanan kesehatan, dan sebagainya, perlu ditunjang atau dibantu oleh promosi kesehatan atau penyuluhan kesehatan. Dalam hal ini, promosi kesehatan bukan hanya penyadaran masyarakat atau pemberian dan peningkatan pengetahuan masyarakat tentang kesehatan saja, tapi juga disertai upaya-upaya memfasilitasi perubahan perilaku. Menurut WHO dalam Notoatmodjo (2007: 23), promosi kesehatan adalah proses untuk meningkatkan kemampuan masyarakat dalam memelihara dan meningkatkan kesehatannya. Hal ini berarti bahwa promosi kesehatan tidak hanya mengaitkan diri pada peningkatan pengetahuan, sikap, dan praktik kesehatan saja, tetapi juga meningkatkan atau memperbaiki lingkungan (baik fisik maupun nonfisik) dalam rangka memelihara dan meningkatkan kesehatan mereka.

\section{PERAN PENDIDIKAN KESEHATAN DALAM KESEHATAN MASYARAKAT}

Menurut Notoatmodjo (2007: 1113), terdapat empat faktor yang mempengaruhi kesehatan. Faktor-faktor tersebut adalah faktor lingkungan (mencakup lingkungan fisik, sosial, budaya, politik, ekonomi, dan lain sebagainya), perilaku, pelayanan kesehatan, dan hereditas (keturunan). Pemeliharaan dan peningkatan kesehatan masyarakat hendaknya dialamatkan pada keempat faktor tersebut. Dengan kata lain, intervensi atau upaya kesehatan masyarakat juga dikelompokkan menjadi intervensi terhadap faktor lingkungan, perilaku, pelayanan kesehatan, dan hereditas.

a) Peran Pendidikan Kesehatan dalam Faktor Lingkungan

Telah banyak fasilitas kesehatan lingkungan yang dibangun 
oleh instansi, baik pemerintah, swasta, maupun Lembaga Swadaya Masyarakat. Selain itu, banyak pula proyek pengadaan sarana sanitasi lingkungan dibangun untuk masyarakat, seperti jamban keluarga, jamban umum, MCK (sarana mandi, cuci, dan kakus), tempat sampah, dan sebagainya. Namun, karena perilaku masyarakat, sarana atau fasilitas sanitasi tersebut kurang atau tidak dimanfaatkan dan dipelihara sebagaimana mestinya. Agar sarana sanitasi lingkungan tersebut dimanfaatkan dan dipelihara secara optimal, maka diperlukan pendidikan kesehatan bagi masyarakat. Demikian pula dengan lingkungan non fisik, akibat masalah-masalah sosial banyak warga masyarakat yang menderita stres dan gangguan jiwa. Oleh karena itu, baik dalam memperbaiki masalah sosial maupun dalam menangani akibat masalah sosial (stres dan gangguan jiwa), diperlukan pendidikan kesehatan.

b) Peran Pendidikan Kesehatan dalam Perilaku

Pendidikan kesehatan merupakan suatu upaya untuk menciptakan perilaku masyarakat yang kondusif untuk kesehatan. Dengan kata lain, pendidikan kesehatan berupaya agar masyarakat menyadari atau mengetahui bagaimana cara memelihara kesehatannya, bagaimana menghindari atau mencegah hal-hal yang merugikan kesehatan mereka dan kesehatan orang lain, ke mana harusnya mencari pengobatan bila sakit, dan sebagainya. Kesehatan bukan hanya diketahui dan disikapi, namun juga harus dilaksanakan dalam kehidupan sehari-hari. Hal ini berarti bahwa tujuan akhir dari pendidikan kesehatan adalah agar masyarakat dapat mempraktikkan hidup sehat bagi dirinya sendiri dan bagi masyarakat, atau masyarakat dapat berperilaku hidup sehat.

c) Peran Pendidikan Kesehatan dalam Pelayanan Kesehatan

Dalam rangka perbaikan kesehatan masyarakat, pemerintah telah menyediakan fasilitas kesehatan masyarakat dalam bentuk Pusat Pelayanan Kesehatan Masyarakat (Puskesmas). Namun, pemanfaatan Puskesmas oleh masyarakat belum optimal, sehingga diperlukan pendidikan kesehatan dalam pelayanan kesehatan bagi masyarakat.

d) Peran Pendidikan Kesehatan dalam Faktor Hereditas

Orang tua, khususnya ibu adalah faktor yang sangat penting dalam mewariskan status kesehatan kepada amak-anaknya. Orang tua yang sehat dan gizinya baik akan mewariskan kesehatan yang baik pula kepada anaknya. Sebaliknya, kesehatan ibu yang rendah dan kurang gizi akan mewariskan kesehatan yang rendah pula kepada anaknya. Rendahnya kesehatan ibu bukan hanya karena sosial ekonominya rendah, namun sering juga disebabkan karena ibu tidak mengetahui bagaimana cara memlihara kesehatannya atau tidak mengetahui makanan yang bergizi yang harus dimakan. Oleh karena itu, pendidikan kesehatan diperlukan pada kelompok ini agar masyarakat atau orang tua menyadari dan melakukan hal-hal yang dapat mewariskan kesehatan yang baik kepada keturunannya.

\section{CORPORATE SOCIAL RESPONSIBILITY}

Perusahaan merupakan sebuah sistem yang tidak dapat berdiri sendiri. Eksistensi perusahaan memberikan pengaruh pada kehidupan sosial, ekonomi, dan budaya masyarakat di sekitarnya, baik secara langsung maupun tidak langsung. Keberadaan perusahaan seringkali menimbulkan dampak negatif terhadap 
lingkungan yang ada di sekitar wilayah operasinya, sehingga merugikan kehidupan masyarakat, seperti penggundulan hutan, kebakaran hutan, pembuangan limbah, dan lain sebagainya. Pengrusakan lingkungan tersebut membuat resah masyarakat, karena membuat mereka mengalami kesulitan dalam memenuhi kebutuhan hidupnya sehari-hari. Namun di sisi lain, perusahaan membutuhkan wilayah operasi yang ada di masyarakat untuk memperoleh keuntungan perusahaan. Inilah yang membuat perusahaan perlu memperhatikan aspek sosial budaya masyarakat dengan membina hubungan baik yang bersifat timbal balik dengan lingkungan di sekitarnya. Artinya, adanya hubungan yang saling menguntungkan antara perusahaan dengan masyarakat, pemerintah, maupun swasta. Hubungan baik ini diciptakan melalui penyelenggaraan program dari perusahaan yang dinamakan Coprorate Social Responsibility (CSR).

Menurut World Business Council

for Sustainable Development dalam Suharto (2009), CSR didefinisikan sebagai berikut:

"Tanggungjawab

Sosial

Perusahaan merupakan komitmen berkesinambungan dari kalangan bisnis untuk berperilaku etis dan memberi kontribusi bagi pembangunan ekonomi, seraya meningkatkan kualitas hidup karyawan dan keluarganya, serta komunitas lokal dan masyarakat luas pada umumnya."

Selain itu, menurut Johnson dan Johnson (2006) dalam Nor (2014), "Corporate Social Responsibility (CSR) merupakan cara perusahaan dalam memanaje proses bisnisnya untuk menghasilkan dampak yang positif terhadap masyarakat secara keseluruhan". Selanjutnya, Elkington (1998) menjelaskan bahwa CSR merupakan bentuk kepedulian perusahaan, di mana perusahaan menyisihan sebagian dari keuntungannya (profit) untuk kepentingan people dan planet secara berkelanjutan dengan prosedur yang tepat serta profesional.

Selain itu, Rudito dan Famiola (2013) mendefinisikan CSR sebagai berikut:

"Secara umum, CSR merupakan peningkatan kualitas kehidupan mempunyai arti adanya kemampuan manusia sebagai individu anggota masyarakat untuk dapat menanggapi keadaan sosial yang ada, dan dapat menikmati serta memanfaatkan lingkungan hidup termasuk perubahan-perubahan yang ada sekaligus memelihara". Oleh karena itu, buku ini sedikit relevan dengan tema "CSR di Bidang Kesehatan Ibu dan Anak."

Mereka pun menjelaskan bahwa pelaksanaan kegiatan CSR haruslah memperhatikan aspek kemanusiaan, sustainable development akan berjalan. Sustainable future ini tidak saja terwujud dengan memperhatikan aspek ekonomi, sosial, dan lingkungan, namun juga memperhatikan aspek human sustainability. Human sustainability dalam hal ini didefinisikan sebagai berikut: "peningkatan kualitas manusia secara etika, seperti pendidikan, kesehatan, rasa empati, saling menghargai, dan kenyamanan yang terangkum dalam tiga kapasitas, yaitu spiritual, emosional, dan intelektual". Dari definisi-definisi tersebut, CSR di bidang kesehatan ibu dan anak ini merupakan salah satu bentuk dari komitmen dan kepedulian perusahaan terhadap kualitas hidup masyarakat, khususnya kesehatan ibu dan anak.

\section{PEMBAHASAN}

Jumlah penduduk Indonesia mengalami peningkatan dari tahun ke tahun. Peningkatan jumlah penduduk tersebut mampu mempengaruhi ketiga indikator kesejahteraan dan pembangunan nasional, yakni ekonomi, pendidikan, dan kesehatan. Meningkatnya jumlah penduduk di Indonesia mengakibatkan 
menurunnya tingkat perekonomian, tingkat pendidikan, dan tingkat kesehatan masyarakat. Hal ini dikarenakan semakin banyak jumlah penduduk berpengaruh terhadap semakin besarnya kesenjangan pendapatan dan sosial antar wilayah, yakni penduduk yang kaya semakin kaya, sementara yang miskin semakin miskin. Kondisi masyarakat yang mengalami kesmiskinan ini tentu berpengaruh terhadap tingkat pendidikan dan kesehatan mereka yang rendah, karena untuk dapat mengakses pelayanan pendidikan dan kesehatan, masyarakat harus memiliki kondisi ekonomi yang cukup untuk membayar biaya pelayanan-pelayanan tersebut.

Tingginya Angka Kematian Ibu dan Anak merupakan salah satu permasalahan yang terjadi di Indonesia dalam bidang kesehatan, sebagai akibat dari rendahnya tingkat ekonomi dan pendidikan masyarakat di bidang kesehatan. Hal ini dapat diketahui dari faktor-faktor penyebab tingginya Angka Kematian Ibu dan Anak di Indonesia yang telah dikemukakan sebelumnya, yakni faktor pendidikan dan perilaku masyarakat yang minim di bidang kesehatan, faktor lingkungan, faktor pelayanan kesehatan, serta faktor status gizi masyarakat yang minim. Oleh karena itu, upaya peningkatan (promosi) kesehatan ibu dan anak hendaknya dialamatkan pada keempat faktor kesehatan tersebut guna menciptakan masyarakat yang mandiri di bidang kesehatan ibu dan anak. Hal ini diungkapkan oleh Notoatmodjo (2005:11) dalam bukunya yang berjudul Promosi Kesehatan dan Ilmu Perilaku.

Selama ini, upaya peningkatan kesehatan ibu dan anak di Indonesia melalui Program Kesehatan Ibu dan Anak telah dilaksanakan oleh pemerintah, sehingga pemerintah selama ini merupakan satu-satunya sektor formal yang memiliki tanggungjawab atas penurunan Angka Kematian Ibu dan Anak di Indonesia. Namun, upaya pemerintah belum berhasil menurunkan laju Angka
Kematian Ibu dan Anak secara cepat. Pemerintah dalam hal ini membutuhkan bantuan berbagai sektor lainnya untuk dapat menurunkan laju Angka Kematian Ibu dan Anak secara cepat. Salah satu sektor yang memiliki potensi untuk berpartisipasi dalam upaya penurunan Angka Kematian Ibu dan Anak di Indonesia adalah perusahaan, melalui program CSRnya.

Promosi kesehatan merupakan bentuk dari upaya peningkatan kesehatan ibu dan anak yang bertujuan untuk menurunkan Angka Kematian Ibu dan Anak secara berkelanjutan, dengan meningkatkan kemandirian masyarakat di bidang kesehatan ibu dan anak. Salah satu perusahaan yang mampu melaksanakan promosi kesehatan melalui program CSRnya adalah PT. Pertamina. Pelaksanaan promosi kesehatan sebagai upaya peningkatan kesehatan ibu dan anak yang dilakukan dalam program CSR di bidang kesehatan ibu dan anak oleh PT. Pertamina, telah dialamatkan pada faktorfaktor kesehatan yang sesuai dengan konsep Notoatmodjo (2005), dan telah terbukti berhasil dalam pelaksanaan programnya, sehingga PT. Pertamina merupakan salah satu contoh perusahaan yang perlu menjadi contoh bagi perusahaan lainnya dalam mengoptimalkan pelaksanaan program CSR di bidang kesehatan ibu dan anak.

\section{PENUTUP}

Kesehatan merupakan salah satu aspek yang memberikan pengaruh terhadap kesejahteraan dan pembangunan nasional, sehingga kesehatan masyarakat perlu menjadi perhatian seluruh pihak, baik pemerintah, masyarakat, maupun perusahaan. Namun, kondisi kesehatan di Indonesia tergolong rendah apabila dibandingkan dengan negara-negara tetangga lainnya. Hal ini salah satunya dipengaruhi oleh Angka Kematian Ibu dan Anak yang masih tinggi di Indonesia.

Dari tahun ke tahun, Angka Kematian Ibu dan Anak di Indonesia 
menurun, namun laju penurunannya lambat, sehingga ini masih menjadi permasalahan. Lambatnya laju penurunan Angka Kematian Ibu dan Anak di Indonesia ini disebabkan oleh pendidikan masyarakat yang minim di bidang kesehatan, faktor lingkungan yang tidak memadai, pemanfaatan pelayanan kesehatan yang tidak optimal, dan status gizi masyarakat yang minim. Pasalnya, kesehatan ibu dan anak merupakan tolok ukur yang penting dalam menciptakan generasi penerus bangsa yang berkualitas, sehingga upaya peningkatan kesehatan ibu dan anak dalam hal ini perlu diupayakan guna menurunkan Angka Kematian Ibu dan Anak sekaligus memperbaiki kondisi kesehatan masyarakat di Indonesia.

Berbagai upaya peningkatan kesehatan ibu dan anak telah dilakukan oleh berbagai pihak, salah satunya oleh perusahaan melalui kegiatan CSRnya. Dalam pelaksanaannya, kegiatan CSR yang dilakukan tersebut hendaknya dialamatkan pada keempat faktor kesehatan, yakni perilaku, lingkungan, pelayanan kesehatan, dan hereditas. Hal ini berarti kegiatan CSR di bidang kesehatan ibu dan anak sudah seharusnya tidak lagi berbentuk charity, seperti pemberian pengobatan gratis dan sejumlah uang, melainkan harus memberikan intervensi terhadap keempat faktor kesehatan tersebut dalam rangka meningkatkan kesehatan ibu dan anak secara berkelanjutan.

\section{DAFTAR PUSTAKA}

Sumber Buku:

Browne, Arthur. 2006. Handbook of Health Social Work. First Edition. Hoboken, New Jersey: Wiley, John and Sons, Inc.

Buku Data dan Informasi Kinerja Pembangunan 2004-2012 Republik Indonesia

Elkington, John. 1998. Canibals With Forks: The Triple Bottom Line in 21st Century Business. Gabriola Island, BC: New Society Publishers
Hadi, Nor. 2014. Corporate Social Responsibility. Yogyakarta: Graha Ilmu Cetakan Kedua

Notoatmodjo, Soekidjo. 2007. Promosi Kesehatan dan Ilmu Perilaku. Jakarta: Rineka Cipta

Rudito, Bambang dan Melia Famiola. 2013. CSR (Corporate Social Responsibility). Bandung: Rekayasa Sains

Suharto, Edi. 2005. Membangun Masyarakat Memberdayakan Rakyat. Bandung: Refika Aditama 2007. Kebijakan Sosial sebagai Kebijakan Publik. Bandung: Alfabeta

2008. Corporate Social Responsibility: What Is and Benefits for Corporate. Jakarta: Majalah Bisnis dan CSR. Vol. 1 No. 4 2009. Pekerjaan Sosial di Dunia Industri: Memperkuat Tanggungjawab Sosial Perusahaan (Corporate Social Responsibility). Bandung: Alfabeta

Sumber Elektronik:

Badan Pusat Statistik Kabupaten Garut.

Kesehatan.

http://garutkab.bps.go.id/index.php ?hal=subject\&id=6 (diakses 8 Mei 2014, pukul 14.09 WIB)

Badan Kependudukan dan Keluarga Berencana Nasional. 2013. Sembilan Indikator Pembangunan Kesehatan Perlu Perhatian Serius. http://www.bkkbn.go.id/ViewBerita. aspx?BeritaID=794 (diakses 21 Juni 2014, pukul 21.11 WIB)

Departemen Kesehatan. 2012. Profil Kesehatan Provinsi Jawa Barat Tahun 2012. www.depkes.go.id/downloads/PROF IL_KES_PROVINSI_2012/12_Profi 1_Kes.Prov.JawaBarat_2012.pdf (diakses 14 Juni 2014, pukul 21.03 WIB)

Fokus Jabar. 2013. Jangan Bangga Tempati Lima Besar Kematian Ibu dan Anak di Jabar. 
http://fokusjabar.com/2013/02/18/jan

gan-bangga-tempati-lima-besar-

kematian-ibu-dan-anak-di-jabar/

(diakses 14 Juni 2014, pukul 0.09)

Kompas. Soal Kesehatan, Indonesia

Tertinggal dari Tetangga. 2013.

http://health.kompas.com/read/201

3/05/22/09522188/Soal.Kesehatan.

Indonesia.Tertinggal.dari.Tetangga

(diakses 8 April 2014, pukul 13.52)

Zainulmukhtar, Nul. 2013. IPM Garut

Masih di Bawah IPB Jabar.

http://www.inilahkoran.com/read/det ail/2054954/ipm-garut-masih-di-

bawah-ipm-jabar (diakses 20

September 2014, pukul 14.17 WIB)

Sumber Lainnya:

Undang-Undang No. 40 Tahun 2007

tentang Perseroan Terbatas

Peraturan Menteri Negara BUMN Tahun

2007 